\title{
Hydraulic parameters in the area of the main dam intake structure of the river
}

\author{
Dilshod Bazarov*, Sukhrob Umarov, Rustam Oymatov, Farokhiddin Uljaev, Khumoyun \\ Rayimov, and Ikboloy Raimova
}

\begin{abstract}
The article presents the study results of changes in flow hydraulic parameters and morphometric elements of the river in the area of the main dam intake structure. A model for studying the direction of flow and other parameters of the flow in the area of the main structure for obtaining water from the Amudarya without a dam has been developed. A functional graph of the depth dependence of the expenditure on the study object was obtained. Graphs of the functional dependence of the diurnal cross-section of the riverbed on the flow depth and the variation of the flow velocity depending on the flow depth were constructed.

The direction and distribution of the flow in the area of the main dam intake structure were studied.
\end{abstract}

\section{Introduction}

One of the largest rivers in Central Asia, the Amudarya, is used for irrigation without dams. One of such large complexes is the Karshi Main Canal pumping station cascade of damfree water intake facilities. Water intake for this cascade is carried out from a shaft near the village of Kyzyloyok in the Republic of Turkmenistan, $19 \mathrm{~km}$ above the Amudarya, in the opposite direction from the Kerki hydropost. The object of scientific research was the Amudarya section, which undergoes rapid deformation processes above the structure of the main water intake structure in this cascade. The Amudarya River, one of the largest rivers in Central Asia, flows through fast-washing soils. In general, the project was planned to build a dam near the village of Kiziloyak to get water from this well to the Karshi Main Canal-KMC. However, in the 70s of the last century, for some reason, the dam was not built due to the high water level in the river and the fact that the guaranteed water intake was guaranteed during the initial period of operation. Changes in the dynamics of flow in the supply of water to the Karshi Main Canal-KMC, both quantitatively and qualitatively, changes in the hydrological and nano regimes of the river complicate the receipt of water from it to the main structure without flooding. The intensity of the ongoing deformation processes makes it difficult to obtain quality and guaranteed water for the main structure. In determining the solution to this problem, it is important to adjust the direction of movement of water flow in this area, to study the dynamics of the hydraulic parameters of the flow.

Extensive research has been conducted in such areas to study the laws of flow

\footnotetext{
* Corresponding author: dr.bazarov@mail.ru
} 
dynamics [1-5].

In late 1940, research into the field revealed that the interaction between current and coastal flow took the form of a kinematic effect, which slowed down the average and surface velocities of water flow [6].

Field research on one of Europe's largest rivers has revealed the effectiveness of eliminating the washing of sedges, which has led to developing a method of planting tree seedlings on the banks to eliminate the process [7].

In general, the formation of torsional motion at the boundary between streams in the riverbed and elsewhere has been recognized. Studies have shown that this process can accelerate the process in rivers such as the Amudarya, where the soil passes through washable soils [8].

As a result of studies conducted in large experimental models in leading European scientific institutions, the flow in the streams was determined as a feature of the division of the stream into streams in riverbeds [9].

As a result of the analysis of the flow characteristic of the flowing river in the Don River, it was recognized that the flow is inclined in the opposite direction, but there is no scientifically based explanation [10-14].

Analysis of the problem of interdependence between channel and flood currents allows calculation of the parameters of such flows [15-17]. The morphological structure of the calculated area has been studied for its determining effect on the hydraulics of flows in flood channels [18-20]. Due to insufficient study of the laws of flow dynamics in the upper section of the river's main dam intake structure in experimental and field studies, this direction was identified as the main goal of the scientific article.

\section{Methods}

The research method of this scientific work is to conduct research in the accepted scale model of the object of study, analyze the obtained results, and assess the dynamics of the hydrological flow regime using the obtained experimental results.

\section{Results and Discussion}

The following experimental model was used to study the flow dynamics in the Amudarya section above the dam of the Karshi Main Canal. 


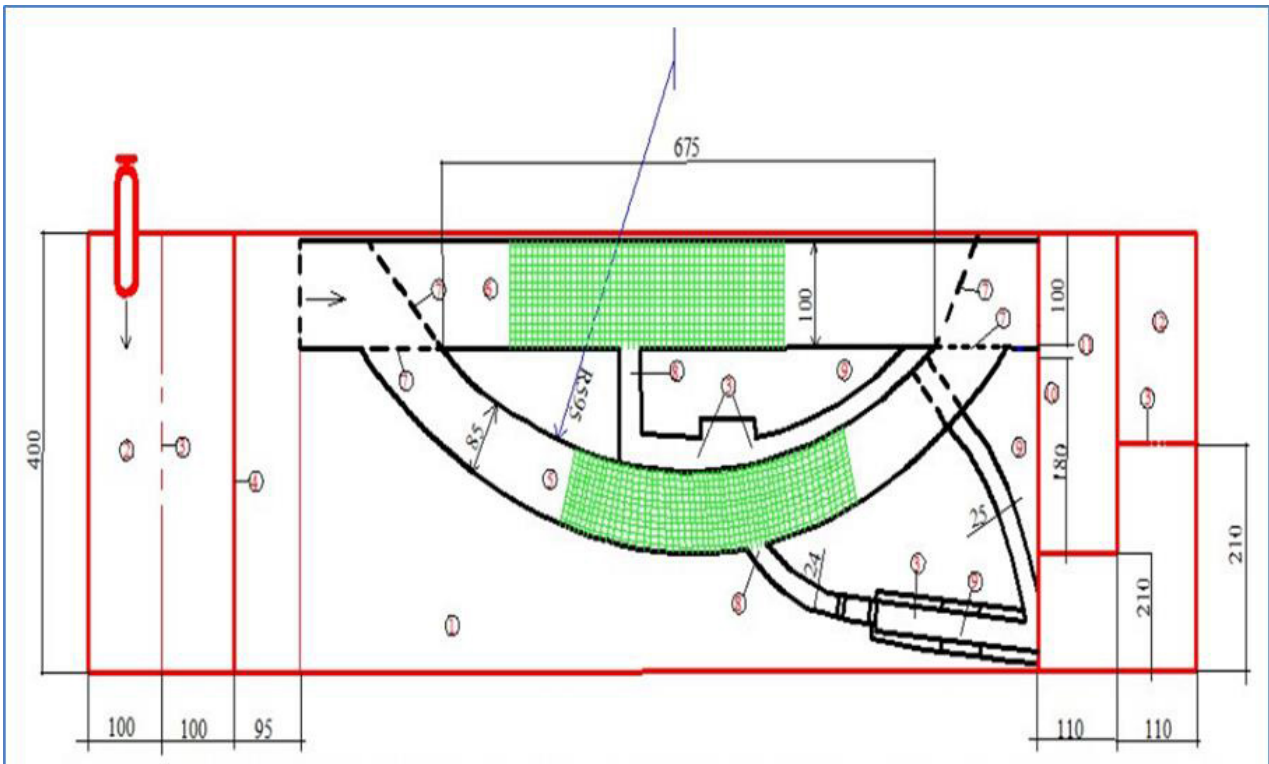

Fig. 1. Schematic of an experimental device

Sand, soil, and gravel (1) were collected in the natural state, which was intended to determine the dredging processes in the dam-free water intake model for the experimental conduction. Water consumption was maintained by means of a pressure tank (2). The flow of water from the pressure tank through the slit (3) through the holes with a diameter of 10 $\mathrm{cm}$ was controlled. The survey was conducted in curved (5) and straight (6) streams. The boundary adjustment structure (7), designed to control the flow of water in curved and straight streams, was constructed by modeling the dimensions of the dam-free water intake channel (8) in kind. In the non-dam intake model, the water flows from the lower bay (9) to the discharge channel (11) through the sluice (10). The collected water was discharged back to the water source through the drainage channel (12).

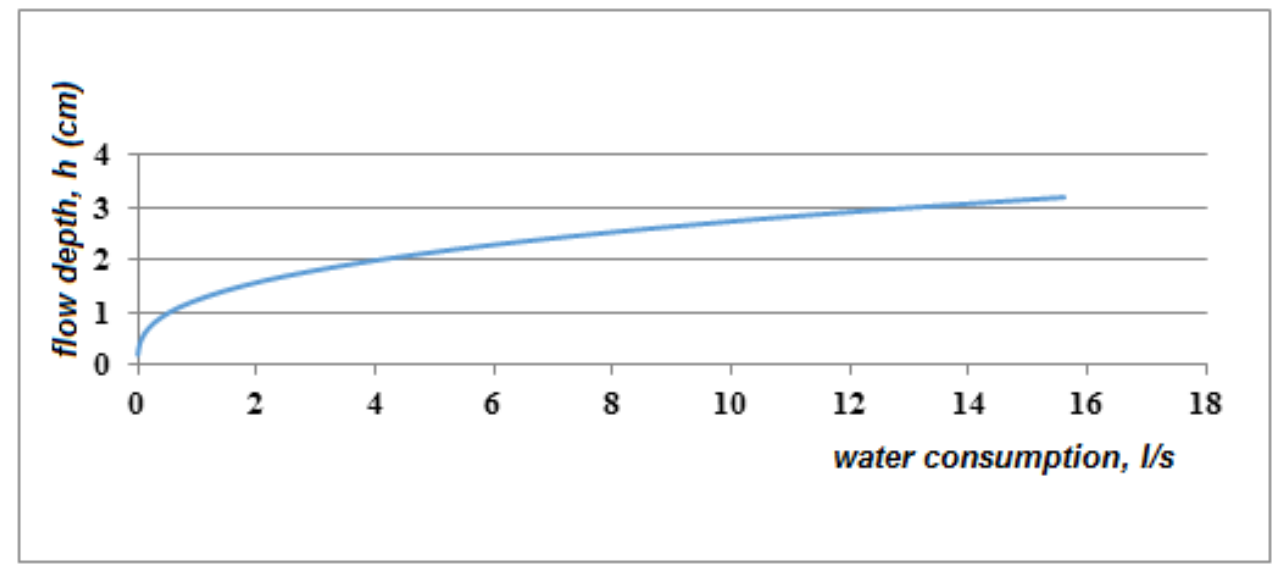

Fig. 2. Changes in water consumption and depth in the process of conducting experimental studies

During the experimental study, changes in flow depths at different water flows were analyzed. In the course of the research, changes in depth and water consumption were observed from 1 shaft located at a distance of $200 \mathrm{~cm}$ before the dam intake. During the 
observations, a graph of the change in water consumption in depth at 1 st was constructed (Fig. 2).

In the experimental studies, the change in water consumption was carried out through the adjusting structure to $\mathrm{Q}=1-18 \mathrm{l} / \mathrm{c}$, the flow rate of water to $\mathrm{V}=0.01-0.08 \mathrm{~cm} / \mathrm{s}$, and the flow depth to $0.5-3.5 \mathrm{~cm}$. In addition to the flow rate of water determined using hydrometric vertigo as part of the study, the water supplied was measured through a trapezoidal Chipoletti aqueduct.

Water consumption in this type of aqueduct was determined using the following formula:

$$
Q=1.86 \cdot b \cdot H^{3 / 2}
$$

The distribution of water flow through the adjustment structure was ensured in the amount required for the study.

The study was conducted in 2 series, and in 1 series, the hydraulic and morphometric parameters of the flow were determined in 3 rows marked on a smooth surface. In series 2 , experimental studies were conducted to adjust the channel using spurs and direct the flow into the water intake channel.

In the 1 st series cross-section 1 the hydraulic performance of the initial state of the flow and the velocity of the flow were determined. The flow rate was measured using a microverter. Based on the identified data, graphs of functional dependence of depth and cross-section in motion were constructed (Figure 3).

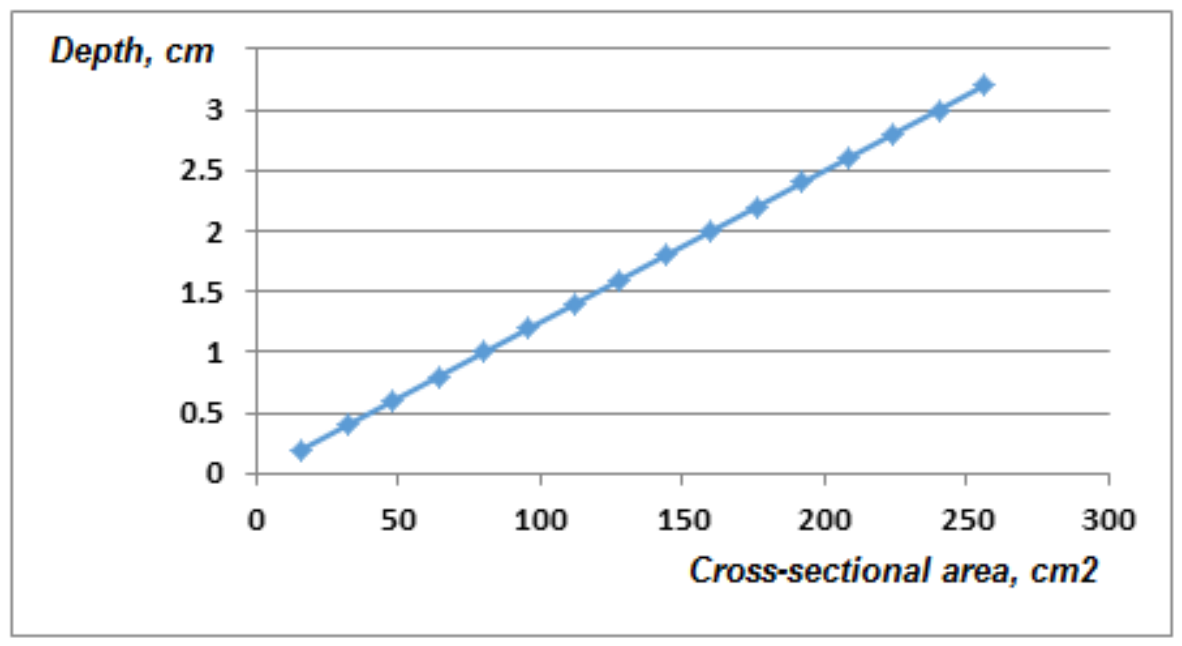




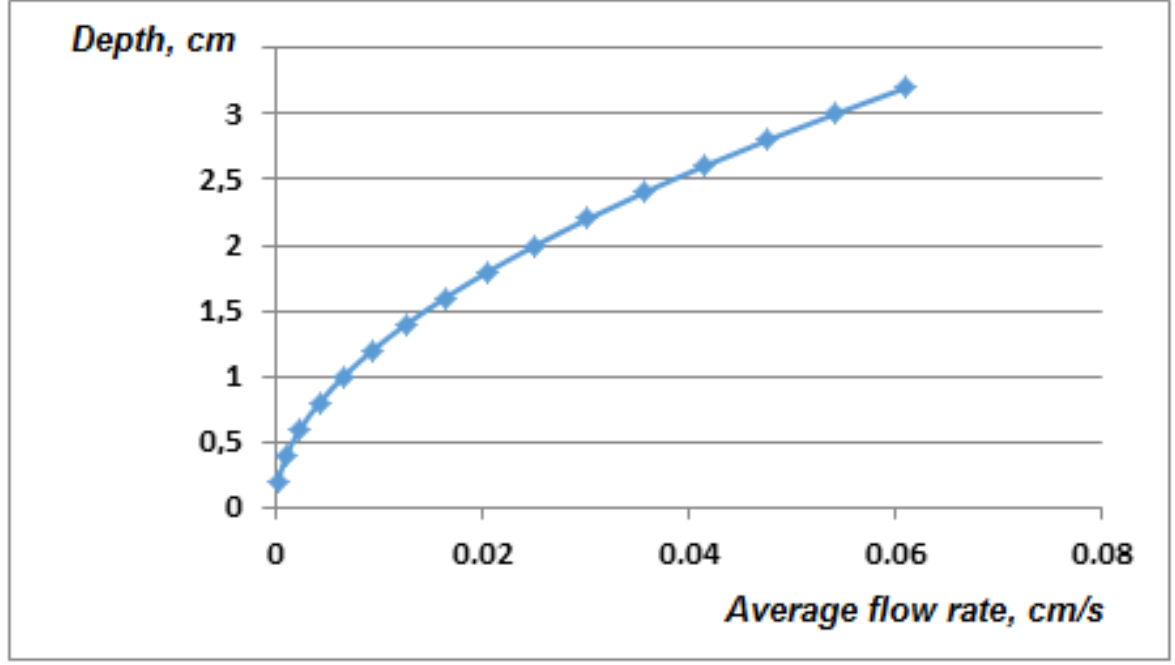

Fig. 3. In preliminary studies, the cross-sectional area and velocity distribution along the flow depth Cross-section 2 the water flow through the damless intake channel, the distribution of the flow, and the flow directions in the area were determined (Figure 4). Data were also obtained to calculate the hydrodynamic parameters of the flow in 2 streams.

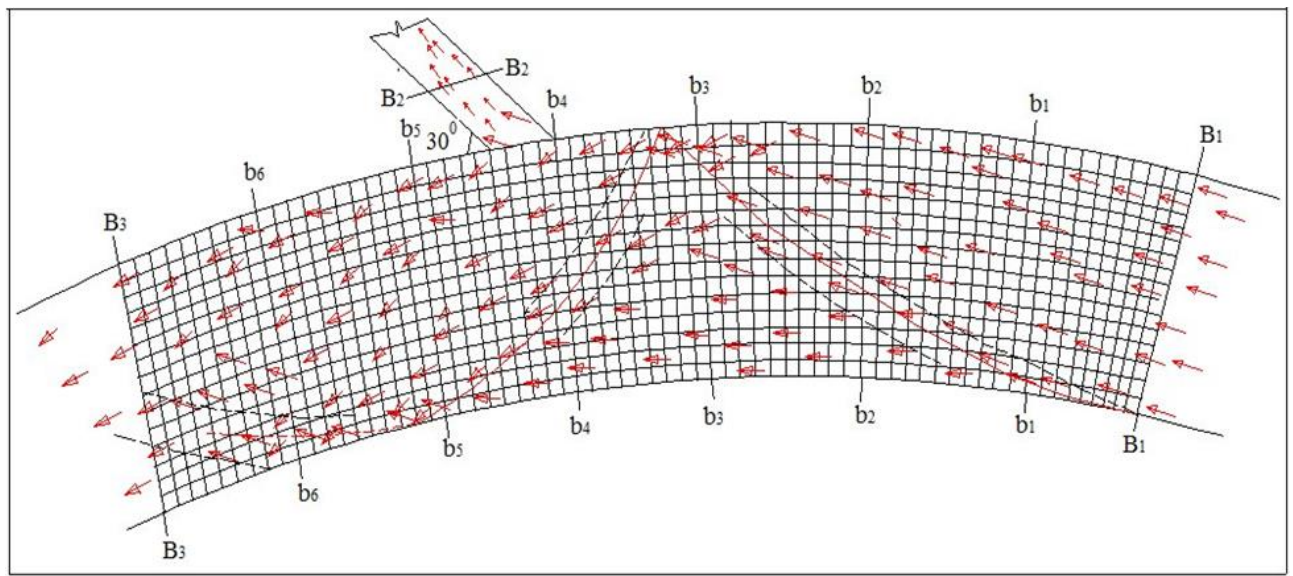

Fig. 4. Appearance of flow direction on a smooth surface

As can be seen from Figure 4, the direction of flow remained unchanged at target range 1. It was observed that the current changed its direction and approached the left bank as it approached the 2 storks. 


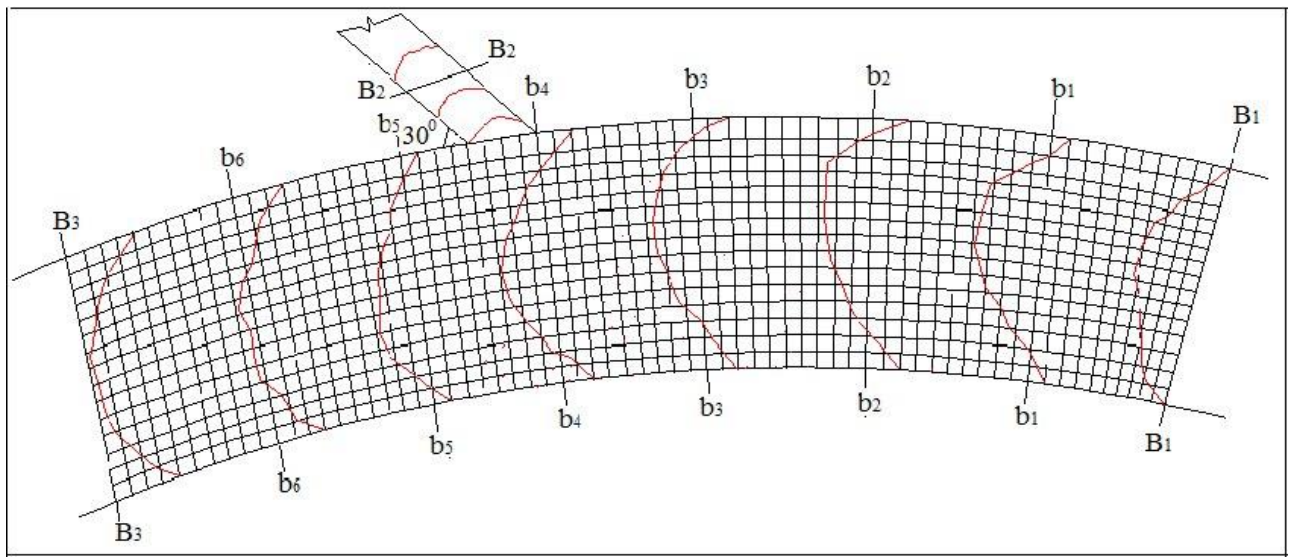

Fig. 5. In preliminary studies, the distribution of water flow rate along the width of the canal. Water intake channel $\alpha=30^{\circ}$

Cross-section 2 the characteristic values of the flow change were obtained. According to him, it can be observed that the depth distribution of velocities in the section after the water intake channel changed when the water consumption changed (Figure 6).

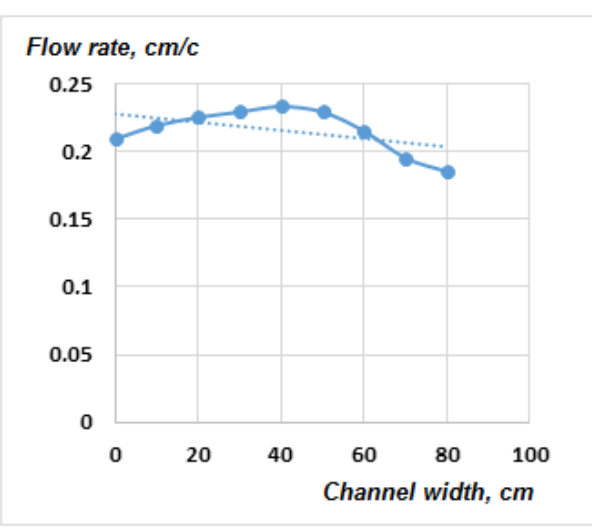

Section № $1, Q=1.5 \mathrm{l} / \mathrm{s}$

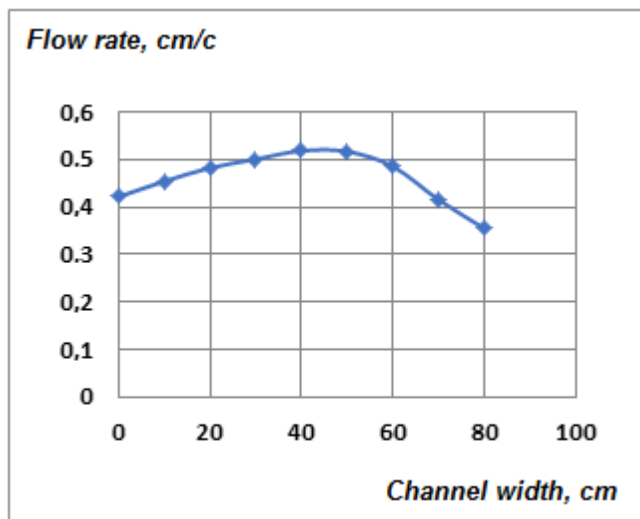

Section № 2, $Q=4.0 \mathrm{l} / \mathrm{s}$

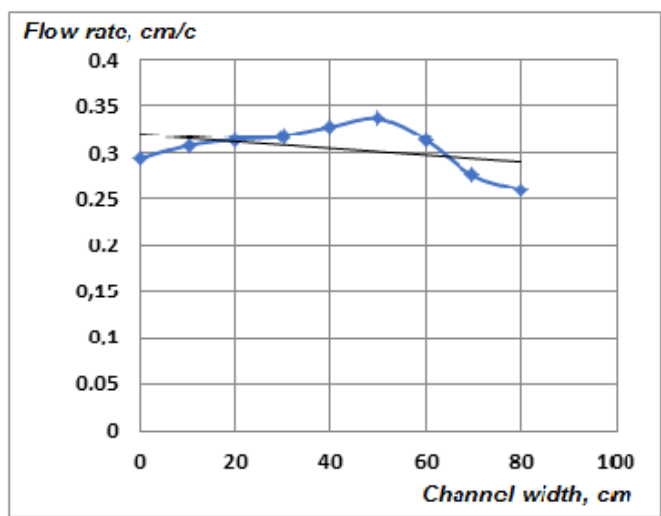

Section № $1, Q=2.9 \mathrm{l} / \mathrm{s}$

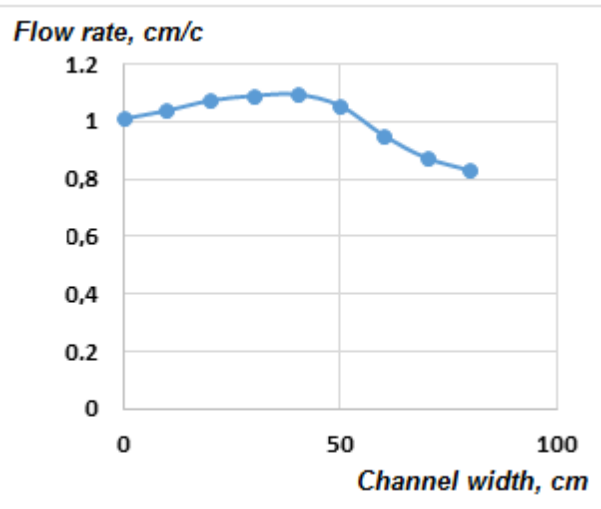

Section № $2, Q=8.0 \mathrm{l} / \mathrm{s}$ 


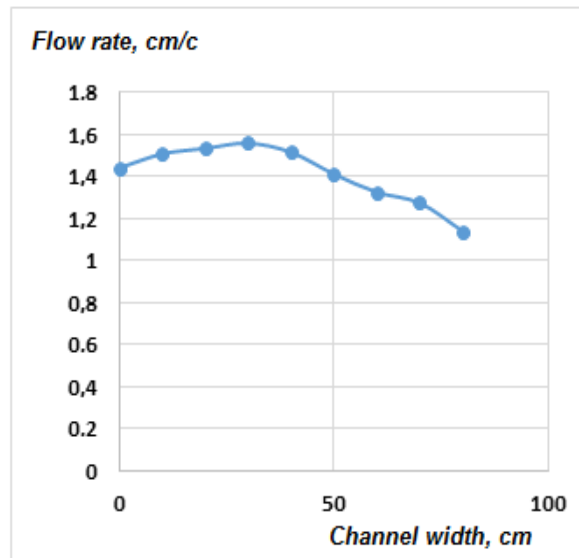

Section № $3, Q=4.0 \mathrm{l} / \mathrm{s}$

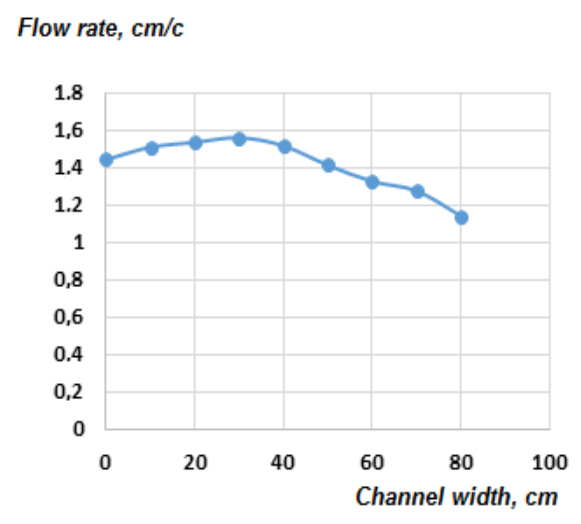

Section № 3, $Q=12.9 \mathrm{l} / \mathrm{s}$

Fig. 6. Connection graphs of channel width and flow rate

In the Amudarya conditions, changes in flow velocity play an important role, so a minimum reduction in velocity was achieved by paying attention to the level of modeling. However, once the stream fully descended to the right bank, the width of the river bed in its regulated part was chosen to be approximately equal to the stable width.

In our scheme, the first protective control dam of $30 \mathrm{~cm}$ length was installed at an angle of $45^{\circ}$ to the convex part of the left bank, the second protective control dam was installed $50 \mathrm{~cm}$ below the first, and the third $50 \mathrm{~cm}$ below the second on the opposite side to the water intake channel.

When dams were installed in this system, the main flow of the channel was limited, the flow rate in the movement zone was reduced. As a result, part of the turbid sediment flow was diverted to the right bank. However, this system did not ensure that the water was directed completely to the right and that the velocity behind the protective control dam was kept to a minimum.

Protective control dam installation schemes have been amended, $30^{\circ}$ at an angle to the convex part of the left bank as in the first scheme, the second protective control dam was installed $50 \mathrm{~cm}$ below the first, and the third $50 \mathrm{~cm}$ below the second on the opposite side to the water intake channel.

The protective control dams are placed parallel to each other at an angle to the incoming flow. The length of the sleepers and the distance between them are assumed to be such that the width of the channel remaining at high flow velocities is equal to the regulated stable width of the river channel. The three-pass protective control dam system narrowed the channel, allowing the flow to turn to the right, towards the head of the water intake structure. The speed behind the protective control dam systems was reduced to a non-zero value (Figure 6.7). 

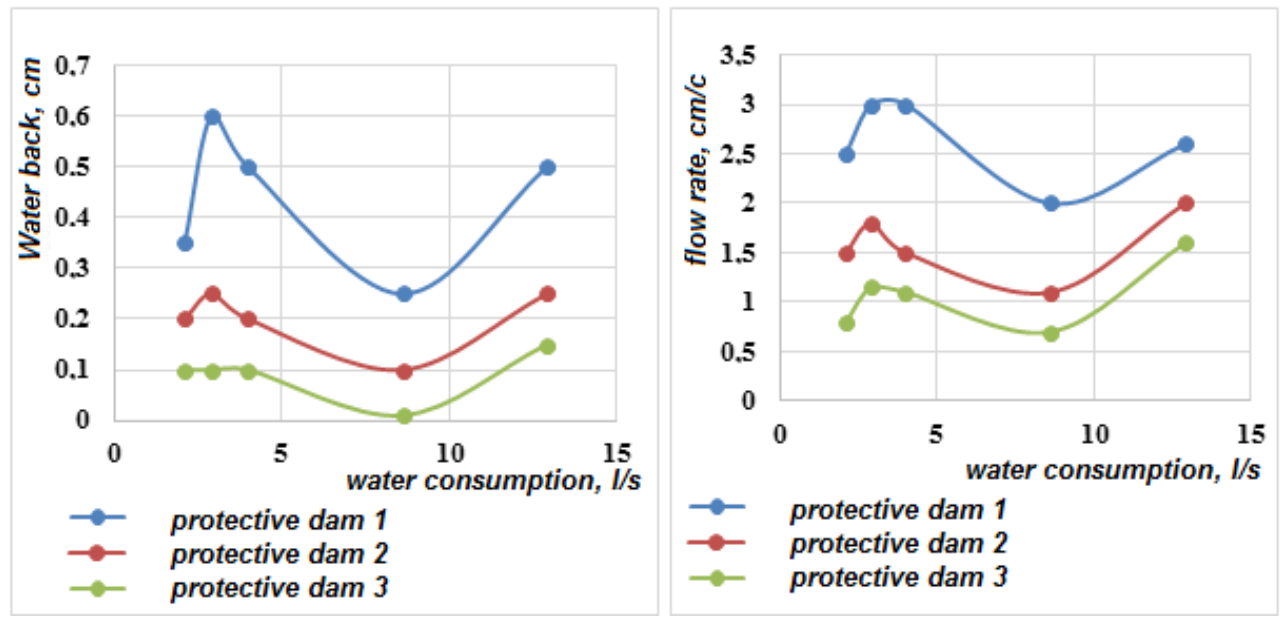

Fig. 7. Dynamics of average flow rate and flow rate in the installation of protective control damshaped adjustment structures. Values were modeled on a 1:60 scale.
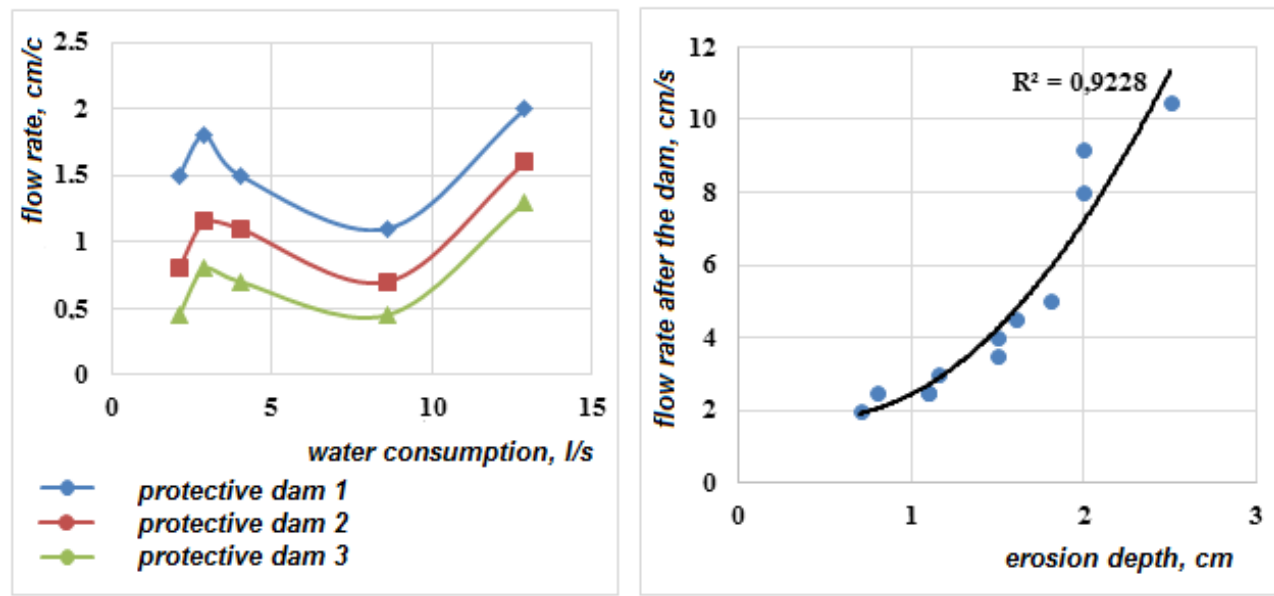

Fig. 8. In the second series of experimental studies, three protective control dams are hydraulic flow elements for the system

Experimental research work was continued to change the direction of flow and facilitate the receipt of water without a dam, and 2 series of experiments were carried out by increasing the number of protective control dams in the system. The number of protective control dams was determined by the method of I.Ya. Orlov. 


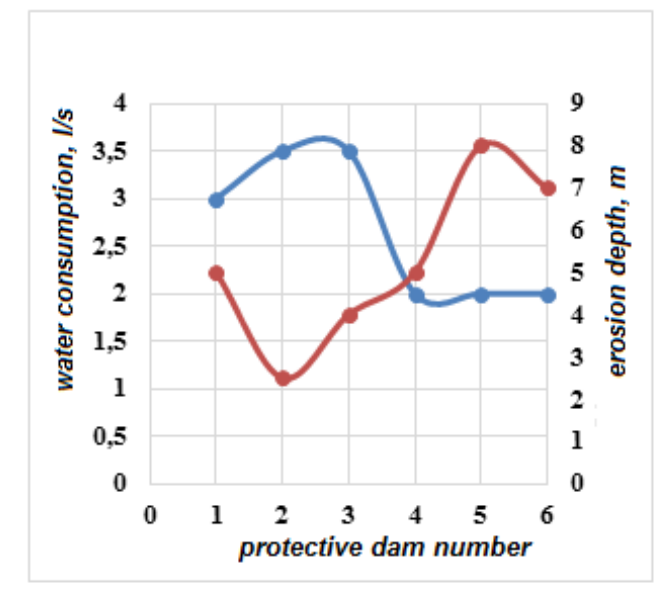

flow rate in front of the protective dam

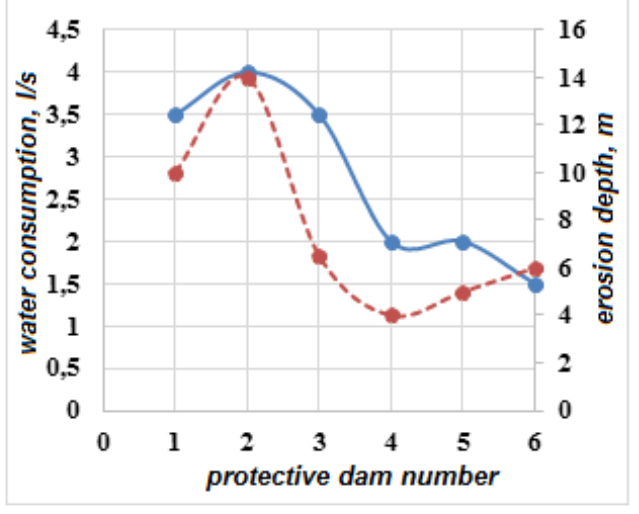

erosion depth

When water consumption is $4250 \mathrm{~m}^{3} / \mathrm{s}$

I, II, III waterproof when the water consumption is $4250 \mathrm{~m}^{3} / \mathrm{s}$

Fig. 8. In the second series of experimental studies, 6 hydraulic flow elements for a protective control dam system

\section{Conclusions}

The following results were obtained in experimental studies:

1. A model for studying the direction of flow and other parameters of the flow in the area of the main structure for obtaining water from the Amudarya without a dam has been developed;

2. A functional graph of the depth dependence of the consumption at the research object was obtained;

3. Graphs of functional dependence of the diurnal section of the riverbed on the flow depth and the change of flow velocity depending on the flow depth;

4. The direction and distribution of the flow in the area of the main water intake without dam was studied;

5. The dynamics of current stagnation near the structure were determined when the flow direction was controlled by the traffic control structures. 


\section{References}

1. Altunin V.S. Intensivnyye deformatsii rusla bluzhdayushchey reki. ILM. Ashkhabad 1975.pp. 102.

2. Bazarov D. R. Nauchnoye obosnovaniye novykh chislennykh metodov rascheta ruslovykh deformatsiy rek, ruslo kotorykh slozheny legkorazmyvayemymi gruntami, p. 249, Moskva, (2000)

3. Bazarov D.R., Ulzhayev F.B., Pulatov S. K., Artykbayeva F., Pulatov S. M. Aspekty resheniya problemy zaregulirovannosti Verkhnego techeniya reki amudar'ya, Web of Scholar 4(22), 1, pp.51-56, (2018)

4. Mukhamedov A.M., Abduraupov P.P., Irmukhamedov K.I. Besplotinnyye vodozabory iz Amudar'i dlya irrigatsionnykh kanalov. Sb. statey "Bor'ba s nanosami v vodozabornykh sooruzheniyakh orositel'nykh kanalov". pp.18-30, Moskva, (1975)

5. Ivanenko Y.G., Tkachev A.A., Ivanenko A.Y. Gidravlicheskiye aspekty ustoychivykh vodnykh potokov $\mathrm{v}$ nerazmyvayemykh i razmyvayemykh ruslakh. Novocherkasskaya gos., meliorativnaya akad, p. 351, Novocherkassk, (2013)

6. Bazarov D., Markova I., Sultanov S. and Kattakulov F. Dynamics of the hydraulic and alluvial regime of the lower reaches of the Amudarya after the commissioning of the Takhiatash and Tuyamuyun hydrosystems IOP Conf. Ser. Mater. Sci. Eng. 1030, 012110 (2021).

7. Bazarov D. and Vokhidov O. Extinguishing Excess Flow Energy in Spillway Structures. In book: Proceedings of EECE 2020, LNCE 150, pp. 535-545, (2021) DOI: 10.1007/978-3-030-72404-7_52

8. Bazarov D., Vatin N., Obidov B., and Vokhidov O. Hydrodynamic effects of the flow on the slab of the stand in the presence of cavitation. IOP Conf. Ser. Mater. Sci. Eng. 1030, 012110 (2021).

9. Bazarov D., Markova I., Norkulov B., Isabaev K., Sapaeva M. Operational efficiency of water damless intake. IOP Conf. Ser. Mater. Sci. Eng. 869(7), 072051, (2020)

10. Bazarov D., Norkulov B., Vokhidov O., Uljaev F., Ishankulov, Z. Twodimensional flow movement in the area of protective regulatory structures. IOP Conf. Ser. Mater. Sci. Eng. 890, 012162 (2020)

11. Krutov A., Choriev R., Norkulov B., Mavlyanova D. and Shomurodov A. Mathematical modelling of bottom deformations in the kinematic wave approximation. IOP Conf. Ser. Mater. Sci. Eng. 1030, 012147 (2021).

12. Krutov A., Norkulov B., Uljaev F., and Jamalov F. Results of a numerical study of currents in the vicinity of a damless water intake. IOP Conf. Ser. Mater. Sci. Eng. 1030, 012121 (2021).

13. Krutov A., Norkulov B., Nurmatov P., Mirzaev M. Applicability of zerodimensional equations to forecast nonconservative components concentration in water bodies. IOP Conf. Ser. Mater. Sci. Eng. 883(1), 012028 (2020)

14. Krutov A., Norkulov B., Artikbekova F., Nurmatov P. Optimal location of an intake at a reservoir prone to salt diffusion. IOP Conf. Ser. Mater. Sci. Eng. 869(7), 072020, (2020)

15. Shokirov B., Norkulov B., Nishanbaev Kh., Khurazbaev M., Nazarov B. Computer simulation of channel processes. E3S Web of Conferences, 97, 05012, (2019)

16. Matyakubov B., Begmatov I., Raimova I. and Teplova G. Factors for the efficient use of water distribution facilities. IOP Conf. Ser. Mater. Sci. Eng. 883, 012025 (2020). 
17. Bazarov D., Markova I., Raimova I., Sultanov Sh. Water flow motion in the vehicle of main channels. IOP Conf. Ser. Mater. Sci. Eng. 883, 012025 (2020).

18. Eshev S., Latipov S., Qurbonov A., Berdiev M., Mamatov N. Non-eroding speed of water flow of channels running in cohesive soils. IOP Conf. Ser. Mater. Sci. Eng. 1030, 012131 (2021).

19. Yangiev A., Eshev S., Panjiev S., Rakhimov A. Calculation of sediment flow in channels taking into account passing and counter wind waves. IOP Conf. Ser. Mater. Sci. Eng., 883, 012036 (2020)

20. Uralov B., Rakhmatov N., Khidirov S., Uljaev F., Raimova I. Hydraulic modes of damless water intake. IOP Conf. Ser. Mater. Sci. Eng. 1030(1), 012123 (2021) 